\title{
Leukemia inhibitory factor inhibits erythropoietin-induced myelin gene expression in oligodendrocytes
}

\author{
Georgina Gyetvai, Cieron Roe, Lamia Heikal, Pietro Ghezzi (DD and Manuela Mengozzi
}

\begin{abstract}
Background: The pro-myelinating effects of leukemia inhibitory factor (LIF) and other cytokines of the gp130 family, including oncostatin M (OSM) and ciliary neurotrophic factor (CNTF), have long been known, but controversial results have also been reported. We recently overexpressed erythropoietin receptor (EPOR) in rat central glia-4 (CG4) oligodendrocyte progenitor cells (OPCs) to study the mechanisms mediating the pro-myelinating effects of erythropoietin (EPO). In this study, we investigated the effect of co-treatment with EPO and LIF.
\end{abstract}

Methods: Gene expression in undifferentiated and differentiating CG4 cells in response to EPO and LIF was analysed by DNA microarrays and by RT-qPCR. Experiments were performed in biological replicates of $N \geq 4$. Functional annotation and biological term enrichment was performed using DAVID (Database for Annotation, Visualization and Integrated Discovery). The gene-gene interaction network was visualised using STRING (Search Tool for the Retrieval of Interacting Genes).

Results: In CG4 cells treated with $10 \mathrm{ng} / \mathrm{ml}$ of EPO and $10 \mathrm{ng} / \mathrm{ml}$ of LIF, EPO-induced myelin oligodendrocyte glycoprotein $(M O G)$ expression, measured at day 3 of differentiation, was inhibited $\geq 4$-fold $(N=5, P<0.001)$. Inhibition of EPO-induced MOG was also observed with OSM and CNTF. Analysis of the gene expression profile of CG4 differentiating cells treated for $20 \mathrm{~h}$ with EPO and LIF revealed LIF inhibition of EPO-induced genes involved in lipid transport and metabolism, previously identified as positive regulators of myelination in this system. In addition, among the genes induced by LIF, and not by differentiation or by EPO, the role of suppressor of cytokine signaling 3 (SOCS3) and toll like receptor 2 (TLR2) as negative regulators of myelination was further explored. LIF-induced SOCS3 was associated with MOG inhibition; Pam3, an agonist of TLR2, inhibited EPO-induced MOG expression, suggesting that TLR2 is functional and its activation decreases myelination.

Conclusions: Cytokines of the gp130 family may have negative effects on myelination, depending on the cytokine environment.

Keywords: Central glia-4, Multiple sclerosis, Myelin oligodendrocyte glycoprotein, SOCS3, TLR2

\section{Background}

Oligodendrocytes (OLs), the myelinating cells of the central nervous system (CNS), produce the myelin sheath that provides physical protection and metabolic support to the axons and allows efficient conduction of action potential (Philips \& Rothstein, 2017). In chronic inflammatory diseases, such as multiple sclerosis (MS), damage to OLs causes demyelination, impairs axonal function and leads to

\footnotetext{
* Correspondence: P.Ghezzi@bsms.ac.uk Department of Clinical and Experimental Medicine, Brighton \& Sussex Medical School, Brighton BN1 9PS, UK
}

progressive degeneration of axons (Franklin \& Gallo, 2014; Tauheed et al., 2016).

Remyelination, the process by which OL progenitor cells (OPCs) differentiate and mature to produce myelin that wraps demyelinated axons, can occur in the adult brain, where a wide-spread population of OPCs is present. Remyelination is usually highly efficient after injury and in the first stages of MS, but declines with aging and disease progression. Remyelination failure is a major determinant of progressive axonal degeneration and permanent neurological disability in chronic demyelinating

(c) The Author(s). 2018 Open Access This article is distributed under the terms of the Creative Commons Attribution 4.0 International License (http://creativecommons.org/licenses/by/4.0/), which permits unrestricted use, distribution, and 
diseases. Since OPCs are present in adult aging brain and in MS lesions, a block in differentiation and not a lack of OPCs seems responsible for remyelination failure (Franklin \& Gallo, 2014; Kremer et al., 2015; Chamberlain et al., 2016).

The main immunomodulating drugs approved for MS can delay disease progression but do not prevent progressive disability since do not repair existing damage. Remyelinating therapies are needed. In the last years, several remyelinating strategies have been attempted, and drugs that inhibit negative signals (e.g. antibodies to LINGO-1) or provide positive stimulation (e.g. clemastine fumarate) are in the translational pipeline, but no remyelinating drugs are currently available (Kremer et al., 2015; Cadavid et al., 2017; Green et al., 2017; Bove \& Green, 2017).

The observations that remyelination can be achieved in aging brain when appropriate exogenous factors are provided (Ruckh et al., 2012) and transplantation of neuronal precursors increases remyelination mainly by immunomodulatory mechanisms (Martino \& Pluchino, 2006) suggest that direct administration of neuroprotective factors, as opposed to transplantation of stem cells, might be a good remyelinating strategy.

In the last 20 years, erythropoietin (EPO) has emerged as a potential candidate for neuroprotective and neuroregenerative treatment in injury and disease of the nervous system (Sargin et al., 2010). Interestingly, EPO improves cognitive performance in healthy animals and humans and in disease, including in MS (Ehrenreich et al., 2007; Robinson et al., 2018; Li et al., 2018). Although the mechanism is still largely unknown, we and others showed that EPO acts directly on OLs to increase myelination in vitro and in vivo (Sugawa et al., 2002; Cervellini et al., 2013; Hassouna et al., 2016; Gyetvai et al., 2017).

In a recent study aimed at identifying cytokines exhibiting protective and regenerative functions similar to EPO by "functional clustering", leukemia inhibitory factor (LIF) emerged as one of the cytokines functionally similar to EPO (Mengozzi et al., 2014).

LIF is a member of the interleukin-6 (IL-6) cytokine family that signals through the LIF receptor (LIFR) and the cytokine receptor glycoprotein 130 (gp130), the latter shared with all the other cytokines of the IL- 6 family, including ciliary neurotrophic factor (CNTF) and oncostatin M (OSM). LIF downstream signaling pathways include the JAK/STAT3, the PI3K/AKT and the MAPK/ERK pathways (Nicola \& Babon, 2015; Davis \& Pennypacker, 2018).

LIF is a pleiotropic cytokine that can have diverse and opposite effects on different cell types, resulting in stimulation or inhibition of cell proliferation, differentiation and inflammation (Nicola \& Babon, 2015; Davis \& Pennypacker, 2018; Slaets et al., 2010; Cao et al., 2011; Linker et al., 2008; Ulich et al., 1994). It is currently believed to play a crucial role in the response to injury, particularly in the CNS (Slaets et al., 2010). Its expression is increased in cerebral ischemia, spinal cord injury, Alzheimer's disease, Parkinson's disease, seizure and MS (Nicola \& Babon, 2015; Slaets et al., 2010; Vanderlocht et al., 2006; Mashayekhi \& Salehi, 2011).

In the CNS, LIF can act on immune, neuronal and glial cells (Davis \& Pennypacker, 2018). Many studies point to a direct action on OLs. In particular, LIF is required in development for the correct maturation of OLs; in addition, in vivo and in vitro, both endogenous and exogenous LIF protect OLs from cell death and increase their proliferation, differentiation and maturation (Nicola \& Babon, 2015; Davis \& Pennypacker, 2018; Slaets et al., 2010; Stankoff et al., 2002; Ishibashi et al., 2006; Emery et al., 2006).

Studies in LIF knock-out mice and exogenous LIF administration have highlighted its protective action in many models of demyelination (Nicola \& Babon, 2015; Davis \& Pennypacker, 2018; Slaets et al., 2010; Emery et al., 2006; Marriott et al., 2008), suggesting the possible therapeutic use of LIF and LIF inducers in demyelinating diseases, including MS (Slaets et al., 2010; Vela et al., 2016; Metcalfe, 2018).

Coadministration of neuroprotective agents rather than a single agent may be more effective. In this regard, EPO was previously reported to synergise with insulin-like growth factor (IGF)-1 to protect against neuronal damage (Digicaylioglu et al., 2004; Kang et al., 2010).

We have previously used an in vitro model of myelination, CG4 OPC transduced to overexpress erythropoietin receptor (EPOR), to study the mechanisms by which EPO increases myelin gene expression (Gyetvai et al., 2017). Aim of this study was to investigate whether co-treatment with EPO and LIF was more effective than EPO alone and the mechanisms involved. Surprisingly, we found that LIF strongly inhibited EPO-induced myelination. By gene expression profiling, we investigated the mechanisms mediating LIF inhibitory effects at the early stage of the OL differentiation process.

\section{Methods}

Cell culture and generation of CG4 cells expressing EPOR

Rat CG4 OPC overexpressing the EPO receptor (CG4-EPOR) were generated and cultured as reported in our previous studies (Cervellini et al., 2013; Gyetvai et al., 2017). As previously shown, wild type CG4 do not express EPOR and do not respond to EPO (Cervellini et al., 2013). However, primary OLs express low levels of EPOR under physiological conditions (Sugawa et al., 2002), and EPOR is induced in the CNS in pathologies where EPO has protective functions (Siren et al., 2001); in particular, injury induces EPOR expression in OLs (Ott et al., 2015). By overexpressing EPOR in CG4 cells, we set up an in vitro system that allowed us to characterise the mechanisms mediating EPO differentiating and myelinating effects in 
OLs, mimicking an in vivo situation of injury or disease, where EPOR would be up-regulated.

CG4-EPOR cells, for simplicity referred to as CG4, were used throughout this study. Briefly, CG4 cells were cultured in poly-L-ornithine-coated 6-well plates (320,000 cells in $4 \mathrm{ml}$ of medium per well). They were maintained at the progenitor stage by culture in growth medium (GM), consisting of Dulbecco's modified Eagle medium (DMEM) (Sigma-Aldrich) supplemented with biotin $(10 \mathrm{ng} / \mathrm{ml})$, basic fibroblast growth factor (bFGF; $5 \mathrm{ng} / \mathrm{ml}$ ), platelet-derived growth factor (PDGF; $1 \mathrm{ng} /$ $\mathrm{ml}$ ), N1 supplement (all from Sigma-Aldrich) and 30\% B104-conditioned medium, obtained as previously reported (Cervellini et al., 2013; Gyetvai et al., 2017). After overnight culture, the cells were induced to differentiate into OLs by switching to differentiation-promoting medium (DM), consisting of DMEM-F12 (Invitrogen/ ThermoFisher Scientific) supplemented with progesterone $(3 \mathrm{ng} / \mathrm{ml})$, putrescine $(5 \mu \mathrm{g} / \mathrm{ml})$, sodium selenite (4 $\mathrm{ng} / \mathrm{ml})$, insulin $(12.5 \mu \mathrm{g} / \mathrm{ml})$, transferrin $(50 \mu \mathrm{g} / \mathrm{ml})$, biotin $(10 \mathrm{ng} / \mathrm{ml})$, thyroxine $(0.4 \mu \mathrm{g} / \mathrm{ml})$ and glucose (3 g/l) (all from Sigma-Aldrich), as reported (Cervellini et al., 2013; Gyetvai et al., 2017). Undifferentiated cells are bipolar; after 2 days of differentiation the cells acquire about $90 \%$ of multipolar morphology. Differentiated CG4 cells express myelin proteins, including MOG, a marker of myelin deposition in these cells (Louis et al., 1992; Solly et al., 1996). After $3 \mathrm{~h}$ in DM, some of the cells were treated with recombinant human EPO (Creative Dynamics), recombinant mouse LIF (Sigma-Aldrich), recombinant rat OSM (Peprotech), recombinant rat CNTF (Peprotech), or Pam3CSK4 (Pam3; InvivoGen). Human EPO is approximately $80 \%$ homologous to rodent EPO, and it is biologically active on rat cells (Gyetvai et al., 2017). Mouse and rat LIF share 92\% sequence homology (Willson et al., 1992), and mouse LIF is biologically active on rat cells (Takahashi et al., 1995).

\section{RNA extraction}

For the microarray experiment, total RNA was extracted and analysed as reported, using the miRNeasy system and protocol (QIAGEN) (Gyetvai et al., 2017). For all the other experiments, total RNA was extracted with QIAzol (QIAGEN), following the instructions of the manufacturer, and RNA purity and concentration were determined using a NanoDrop ND-1000 (NanoDrop Technologies/ThermoFisher Scientific).

\section{RT-qPCR}

Reverse transcription (RT) and real time qPCR were carried out as reported (Gyetvai et al., 2017; Mengozzi et al., 2012), using $\mathrm{TaqMan}^{\circ}$ gene expression assays (Applied Biosystems/ThermoFisher Scientific) and Brilliant III qPCR master mix (Stratagene/Agilent Technologies).
Gene expression was quantified using the $\Delta \Delta \mathrm{Ct}$ method, according to Applied Biosystems' guidelines. Results were normalized to HPRT1 expression (reference gene) and expressed as fold change (FC) or as $\log _{2}$ FC vs one of the control samples, chosen as the calibrator, as previously reported (Mengozzi et al., 2012).

\section{Microarrays}

All experimental conditions were performed in quadruplicate; undifferentiated cells were cultured in quadruplicate but only 3 random samples were used for microarray analysis and all of the 4 samples for qPCR validation. Results from 27 arrays are analysed and presented in this study: 3 undifferentiated (undif) and 4 differentiated (dif), 4 differentiated+EPO (EPO), 4 differentiated+EPO + LIF (EPO + LIF) at each time point (at $4 \mathrm{~h}$ and $23 \mathrm{~h}$ of differentiation; $1 \mathrm{~h}$ and $20 \mathrm{~h}$ after treatment with EPO and LIF respectively). RNA was amplified, labelled and hybridised onto Single Colour SurePrint G3 Rat GE 8x60K Microarrays (AMADID:028279; Agilent) at Oxford Gene Technology, Oxford, UK. Following hybridisation, the arrays were scanned to derive the array images. Feature extraction software v10.7.3.1 was used to generate the array data from the images.

\section{Microarray data analysis}

Raw data in standard format from the microarray experiment have been deposited in the Gene Expression Omnibus (GEO) database of the National Center for Biotechnology Information (NCBI) (Barrett et al., 2013) and are accessible through GEO Series accession number GSE84687 (http://www.ncbi.nlm.nih.gov/geo). Raw data were normalised and analysed using GeneSpring (Agilent) and Excel (Microsoft) softwares. Transcript expression levels $\left(\log _{2}\right.$ of the gProcessed Signal) between the experimental groups were compared by Student's $t$ test, obtaining uncorrected $P$ values. Subsequent multiple comparison corrections were performed using the Benjamini-Hochberg (BH) False Discovery Rate (FDR) procedure, obtaining adjusted $P$ values (BH adj. $P$ values). Fold change in the expression was calculated as the ratio between the average of the gProcessed Signals of the various groups and expressed as $\log _{2}$. Differences in expression with a $\mathrm{BH}$ adj. $P$ value $<0.05$ and an absolute fold change $\geq 1.5\left(\log _{2}\right.$ fold change $\left.\geq 0.58\right)$ were considered statistically significant.

Functional annotation and biological term enrichment was performed using the DAVID v6.8 database (Database for Annotation, Visualization and Integrated Discovery) available online (https://david.ncifcrf.gov) (Huang da et al., 2009). Categories with $P$ values $<0.05$ were considered significantly enriched.

Gene-gene interaction networks were visualised using the STRING v10.5 database (Search Tool for the Retrieval of 
Interacting Genes/Proteins) available online (http://string-db.org). STRING assigns to each reported functional association a confidence score, which is dependent on both the experimental method on which the functional association prediction is based, and on the reliability of computational approaches used for prediction. We used all active prediction methods, and a confidence score $>0.4$.

\section{Results}

LIF induces MOG with a bell-shaped dose response curve CG4 cells, a largely used in vitro model of myelination, can be differentiated to produce myelin proteins, including myelin basic protein (MBP), a marker of differentiation, and MOG, a marker of myelin deposition(Louis et al., 1992; Solly et al., 1996). In previous studies, we have validated this model and shown that expression of MOG mRNA correlated with production of the protein, measured by western blot (Cervellini et al., 2013). Therefore, in this study we measured MOG mRNA as a marker of myelination in differentiated CG4 cells.

CG4 cells were differentiated for 3 days in DM with or without increasing concentrations of LIF ranging from 0.004 to $10 \mathrm{ng} / \mathrm{ml}$. LIF increased MOG expression with a peak at $0.2 \mathrm{ng} / \mathrm{ml}$ and had no effect at the higher dose of $10 \mathrm{ng} / \mathrm{ml}$, showing a bell-shaped dose response curve (Fig. 1a). In contrast, our previous results had shown that in these cells EPO still increased MOG expression at high doses, up to $400 \mathrm{ng} / \mathrm{ml}$, although the expression plateaus after $10 \mathrm{ng} / \mathrm{ml}$ (Cervellini et al., 2013).

\section{LIF inhibits EPO-induced MOG expression}

To investigate whether LIF synergised with EPO in increasing MOG expression, the cells were co-stimulated with EPO at $10 \mathrm{ng} / \mathrm{ml}$ and with LIF at 0.2 and $10 \mathrm{ng} / \mathrm{ml}$. No synergistic or additive effect was observed; surprisingly, LIF markedly inhibited EPO-induced MOG expression at the high dose $(10 \mathrm{ng} / \mathrm{ml}$, Fig. 1b), and some inhibition was also observed at the low dose $(0.2 \mathrm{ng} / \mathrm{ml}$, Fig. 1c), which had a positive effect on $M O G$ induction when added alone (Fig. 1a). Since EPO at high doses still increased MOG expression in these cells, as mentioned above and reported in a previous study (Cervellini et al., 2013), whereas LIF was less effective at high dose (10 ng/ $\mathrm{ml})$ than at low dose $(0.2 \mathrm{ng} / \mathrm{ml}$; Fig. 1a), these results suggest the LIF might induce a negative feedback that inhibits both its own and EPO's pro-myelinating effects.

Of note, LIF at $10 \mathrm{ng} / \mathrm{ml}$ inhibited also EPO-induced myelin basic protein (MBP) expression at the same time point (at day 3 of differentiation): $M B P$ mRNA as FC vs control, mean $\pm \mathrm{SD}, N=8$; EPO: $3.7 \pm 1.3, P<0.001$ vs control; EPO + LIF: $1.5 \pm 0.4, P<0.001$ vs EPO alone by two-tailed Student's $t$-test).
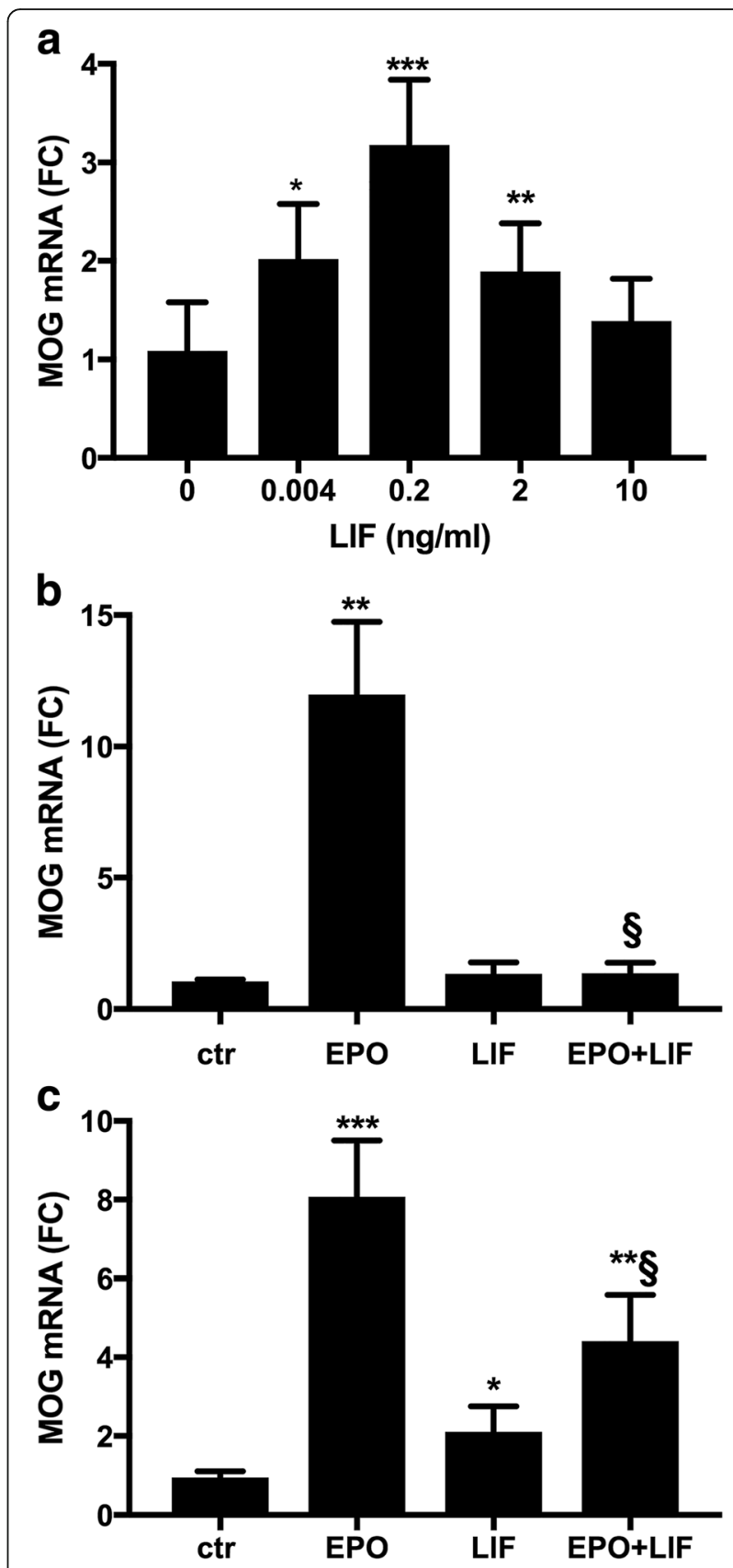

Fig. $1 \mathrm{LIF}$ induces MOG mRNA with a bell-shaped dose-response curve and inhibits EPO-induced MOG expression. Cells cultured for 1 day in growth medium (GM) were switched to differentiation medium (DM). After $3 \mathrm{~h}$ in DM the cells were treated with the indicated concentrations of LIF (a) or with or without EPO $(10 \mathrm{ng} / \mathrm{ml})$ and LIF (10 ng/ml, panel b; $0.2 \mathrm{ng} / \mathrm{ml}$, c). MOG gene expression was measured by RT-qPCR at day 3 of differentiation. Results are expressed as fold change (FC) vs one of the control samples (no LIF in panel $\mathbf{a}$ and ctr in $\mathbf{b}$ and $\mathbf{c}$ ). Data are the mean \pm SD of seven samples from two independent experiments assayed in duplicate (a) or of quadruplicate samples assayed in duplicate and representative or five (b) or two (c) independent experiments; ${ }^{*} P<0.05$, ${ }^{*} P<0.01,{ }^{* * *} P<0.001$ vs control; $\S P<0.01$ vs EPO alone by two-tailed Student's $t$-test 


\section{LIF-induced changes in gene expression}

To investigate the mechanisms by which LIF inhibits EPO-induced myelin gene expression, we performed a gene expression microarray study to identify the genes regulated by LIF in cells co-cultured with EPO and LIF, in which EPO-induced myelin gene expression was inhibited. We reasoned that co-culture with LIF might inhibit the effect of EPO by two mechanisms: i) inhibiting the expression of "positive regulators" of myelination increased by EPO; ii) increasing the expression of "negative regulators" of myelination, which are likely to be unchanged or decreased by differentiation or by EPO.

Analysis of the transcripts regulated by differentiation and further regulated by addition of EPO at $1 \mathrm{~h}$ and $20 \mathrm{~h}$ has been reported elsewhere (Gyetvai et al., 2017). Here we focussed on the genes regulated by LIF, selected by comparing EPO + LIF vs EPO at $1 \mathrm{~h}$ and $20 \mathrm{~h}$ and setting a fold change (FC) cut-off of $1.5\left(\log _{2}\right.$ FC 0.58$)$ and $P$ value $<0.05$ after applying the $\mathrm{BH}$ correction for multiple tests.

\section{Negative regulators of myelination induced by LIF at $1 \mathrm{~h}$} The gene expression profile of EPO-treated CG4 cells at $1 \mathrm{~h}$ and the effect of differentiation alone, previously reported (Gyetvai et al., 2017), is summarised in Fig. 2a; differentiation affected 878 genes, of which 461 were upregulated and 417 downregulated; treatment of differentiating cells with EPO for $1 \mathrm{~h}$ affected only 5 genes, which were all upregulated. Only 3 of these were affected and further increased by LIF (Fig. 2a and Additional file 1).

Since at the early time point LIF did not inhibit any EPO-induced gene, we focussed on the idea that it might induce negative regulators of myelination, whose expression would likely be either unchanged or decreased by culture in DM with or without EPO. When comparing EPO + LIF vs EPO, 82 genes were increased (Fig. 2a). Of these, 7 genes were excluded because they were also increased by differentiation alone (4, Additional file 2 ) or by EPO (3, Additional file 1). Therefore 75 genes that were either downregulated or not changed by differentiation, not altered by EPO and finally upregulated by LIF remained.

Network analysis of the remaining 75 genes $(28+47$, Fig. 2a) using the STRING database highlighted hubs centered on STAT3 and SOCS3 which included Myd88, part of toll-like receptor (TLR) signaling (Fig. 2b). A list of all the 75 genes, their fold change in expression levels by LIF (EPO + LIF vs EPO) and by differentiation (differentiated vs undifferentiated) is reported in Additional file 3.

\section{EPO-induced positive regulators of myelination inhibited by LIF at $20 \mathrm{~h}$}

The gene expression profile of EPO-treated CG4 cells and the effect of differentiation at $20 \mathrm{~h}$ have been previously reported (Gyetvai et al., 2017). In Fig. 3a, the genes affected by LIF have been included.
At this time point EPO increased the expression of a number of genes, potential positive regulators of myelination, including 43 genes upregulated also by differentiation alone and 113 unaffected by differentiation. Addition of LIF decreased 7 of the 43 genes increased by EPO and differentiation, and 9 of the 113 genes increased only by EPO, as summarized in the Venn diagram in Fig. 3b (left). We focussed on the 16 putative positive regulators of myelination inhibited by LIF (green arrows, Fig. 3b), listed in Table 1. Functional annotation analysis of this subset of genes using the DAVID software highlighted enriched gene ontology biological process (GO:BP) and KEGG pathways categories involved in fatty acid transport, storage and oxidation; genes belonging to these categories included $C D 36$, Pnlip, Plin2, Ppargc1a (Table 2). Of note, LIF inhibited also Ptpre, a protein tyrosine phosphatase which, among other effects, inhibits MAPK/ERK activation and that we previously identified as one of the top EPO-induced genes (Gyetvai et al., 2017).

Negative regulators of myelination induced by LIF at $20 \mathrm{~h}$ As at the $1 \mathrm{~h}$ time point, we then searched for potential LIF-induced negative regulators at $20 \mathrm{~h}$. These were selected by comparing EPO + LIF and EPO and setting a cut-off of $\mathrm{FC}>1.5\left(\log _{2} \mathrm{FC}>0.58\right)$ and $\mathrm{BH}$ adj. $P$ value < 0.05. As shown in Fig. 3a and in the Venn diagram in Fig. 3b (right), among the transcripts unchanged by either EPO and/or differentiation alone, we identified 256 genes increased by addition of LIF; out of 1272 genes decreased by differentiation, 69 genes were increased by LIF; among the 37 genes downregulated by EPO, 2 were increased by LIF. In total, 327 genes unchanged or decreased by differentiation or EPO were increased by LIF (full list Additional file 4).

STRING interaction analysis of the 71 genes induced by LIF and also decreased by differentiation (69) or EPO (2) (right red arrows, Fig. 3b), and therefore more likely to be putative negative regulators of myelination, highlighted a network of highly connected genes focused around STAT3, SOCS3 and TLR2 (Fig. 3c).

\section{High expression of LIF-induced SOCS3 is associated with reduced $M O G$ expression}

Since SOCS3, downstream of STAT3, was highly induced by LIF at both time points, and its expression in OLs can inhibit LIF-induced myelination in vivo in mice (Emery et al., 2006), we explored further its involvement in LIF-mediated inhibition of myelination.

The mRNA expression of SOCS3 from the microarray experiment was validated by RT-qPCR using the same RNA used for the microarray experiment; inhibition of SOCS3 by differentiation and induction by LIF at $1 \mathrm{~h}$, reported in Additional file 3, were confirmed (SOCS3 mRNA as $\log _{2} \mathrm{FC}$, mean $\pm \mathrm{SD}, N=4$; 


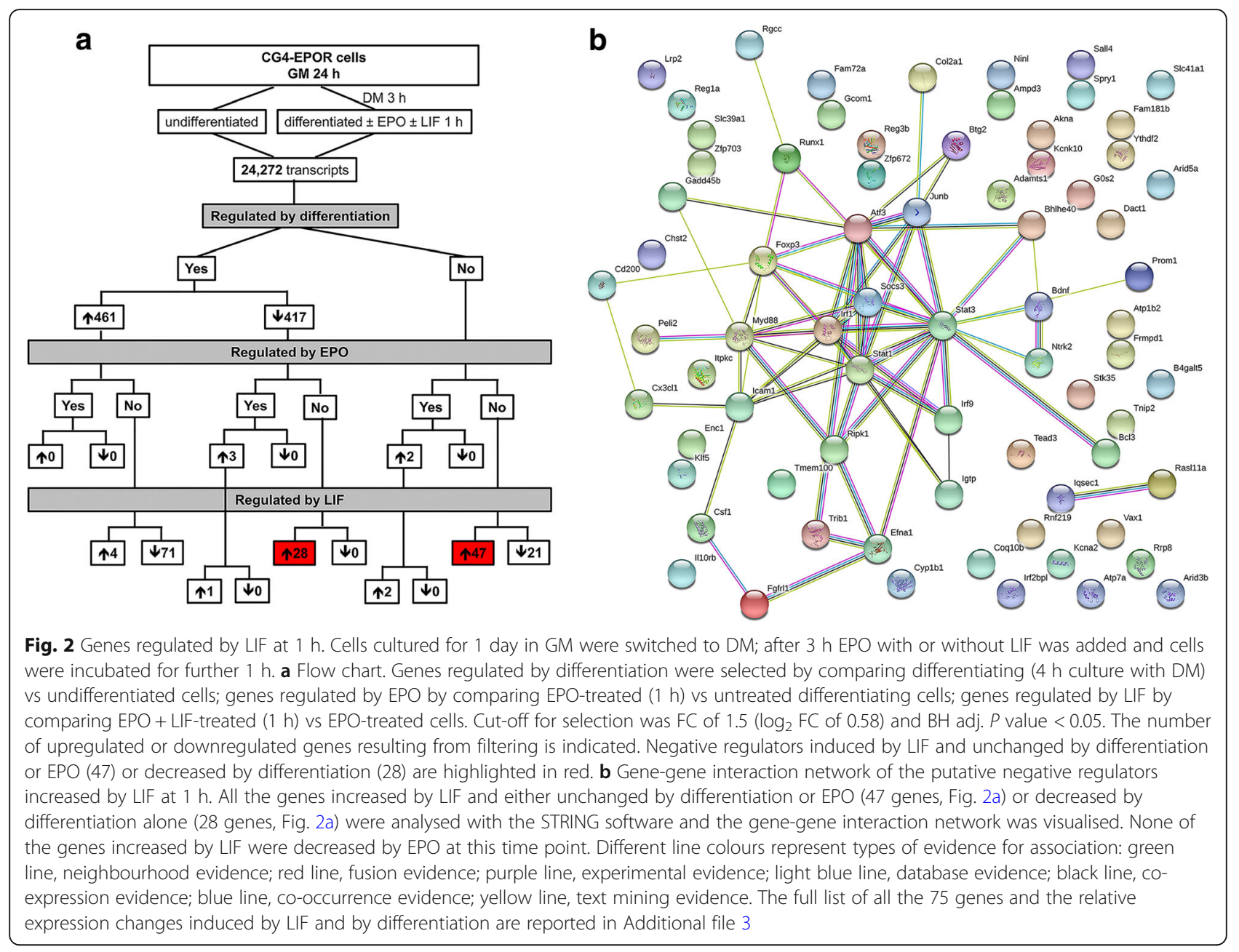

dif vs undif: $-2.8 \pm 0.2, P<0.001$; EPO + LIF vs EPO: $1.9 \pm 0.3, P<0.001$ by two-tailed Student's $t$-test).

In independent experiments, SOCS3 expression was dose-dependently induced by LIF (Fig. 4a). Furthermore, co-stimulation of EPO-treated cells with LIF which, as shown in Fig. 1b, inhibits EPO-induced $M O G$ expression, induced high levels of SOCS3 at $1 \mathrm{~h}$ (Fig. 4b).

The association between MOG inhibition and induction of high levels of SOCS3 was confirmed with OSM or CNTF, cytokines also belonging to the IL- 6 family. At concentrations equimolar to the high dose of LIF $(10 \mathrm{ng} / \mathrm{ml})$, also OSM and CNTF inhibited EPO-induced MOG (Fig. 4c), and induced high levels of SOCS3 at $1 \mathrm{~h}$ (SOCS3 mRNA as FC vs control, mean $\pm \mathrm{SD}, N=4$; OSM: $8.1 \pm 1.7, P<0.001$; CNTF: $5.2 \pm 1.7, P<0.01$ by two-tailed Student's $t$-test). Of note, at a lower dose $(0.13 \mathrm{ng} / \mathrm{ml})$, equimolar to $0.2 \mathrm{ng} / \mathrm{ml}$ of LIF, OSM induced MOG expression, whereas CNTF had no effect (SOCS3 mRNA as FC vs control, mean $\pm \mathrm{SD}, N=4$; OSM: $3.2 \pm 0.7, P<0.001$; CNTF: $1.4 \pm 0.2, P=0.19$ by two-tailed Student's $t$-test).

\section{TLR2 engagement inhibits EPO-induced MOG}

Among the negative regulators induced by LIF, TLR2 was also highlighted as a highly connected hub by STRING analysis at $20 \mathrm{~h}$ (Fig. 3c). Microarray expression of TLR2 was validated by RT-qPCR using the same RNA used for the microarray experiment, confirming the inhibition of TLR2 by differentiation and the very high induction by LIF at $20 \mathrm{~h}$ reported in Additional file 4 (TLR2 mRNA as $\log _{2} \mathrm{FC}$, mean $\pm \mathrm{SD}, N=4$; dif vs undif: $-1.5 \pm 0.5, P<0.01$; EPO + LIF vs EPO: $3.6 \pm 0.3, P<$ 0.001 by two-tailed Student's $t$-test).

We therefore assessed the functional relevance of this finding using the TLR2 agonist Pam3. As shown in Fig. 4d, TLR2 activation inhibited EPO-induced MOG expression at the same extent as LIF and potentiated LIF inhibition.

\section{Discussion}

Although there is ample evidence in the literature that LIF and other cytokines of the IL-6 family, including CNTF, have pro-myelinating activities in vivo and in vitro (Nicola \& Babon, 2015; Davis \& Pennypacker, 2018; Slaets et al., 2010; Metcalfe, 2018), we report here 


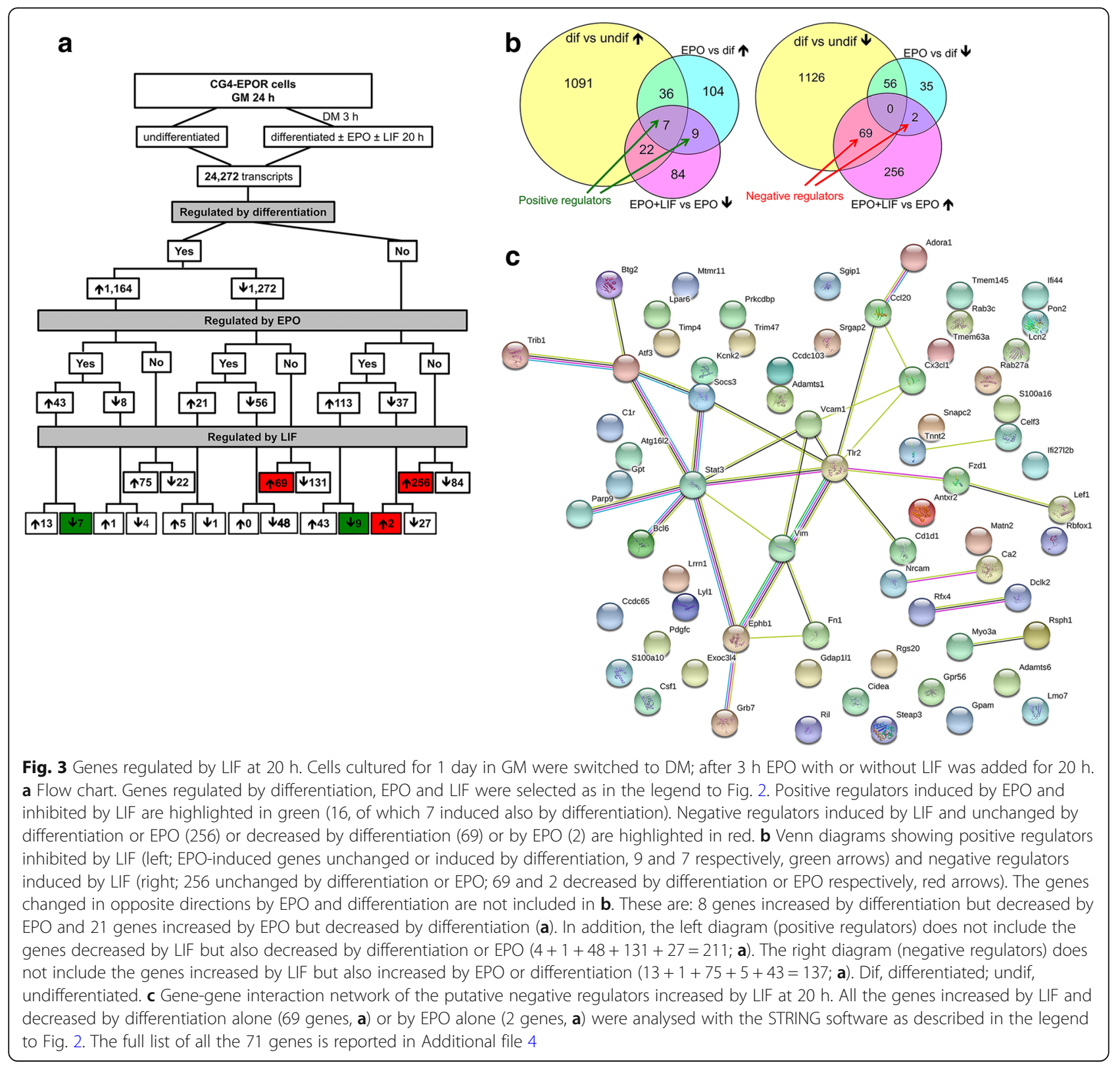

that LIF can inhibit myelination in vitro. Specifically, in CG4 OPC induced to differentiate into OLs in the presence of EPO, co-treatment with LIF inhibited EPO-induced MOG expression. Of note, LIF inhibition was observed in CG4 cells transduced to overexpress EPOR, and therefore optimised to respond to EPO. We had previously used this in vitro system to study the mechanisms by which EPO increased myelin gene expression (Gyetvai et al., 2017), using MOG as a readout since its expression is associated with myelin deposition in these cells (Solly et al., 1996). Compared to cells incubated in DM alone, treatment with EPO consistently induced high levels of MOG expression, which were strongly inhibited by LIF. The effect was more marked at high LIF concentrations $(10 \mathrm{ng} / \mathrm{ml})$, but inhibition was also noted at lower concentrations $(0.2 \mathrm{ng} / \mathrm{ml})$, which per se could slightly increase $M O G$ expression. All together these observations highlight the strength of the inhibitory effect of LIF.

Our data may seem in contrast with many studies observing LIF pro-myelinating effects (Nicola \& Babon, 2015; Davis \& Pennypacker, 2018; Slaets et al., 2010; Metcalfe, 2018). However, no effect of LIF on OL differentiation had been previously described (Barres et al., 1993; Kahn \& De Vellis, 1994; Park et al., 2001); interestingly, one study reported inhibitory effects of high LIF doses (more than $5 \mathrm{ng} / \mathrm{ml}$ ) on OPC differentiation (Ishibashi et al., 2006). The ability of LIF to inhibit the 
Table 1 Genes increased by EPO and inhibited by LIF at $20 \mathrm{~h}$

\begin{tabular}{|c|c|c|c|c|c|}
\hline \multirow[t]{2}{*}{ ProbeName } & \multirow[t]{2}{*}{ Gene } & \multicolumn{2}{|c|}{ EPO + LIF vs EPO } & \multicolumn{2}{|c|}{ EPO vs differentiation } \\
\hline & & $\log _{2} \mathrm{FC}$ & $\overline{\text { BH adj.P }}$ & $\log _{2} \mathrm{FC}$ & BH adj.P \\
\hline A44P792784 & Htr2C & -1.98 & $6.0 \mathrm{E}-04$ & 5.14 & $5.1 \mathrm{E}-05$ \\
\hline A64P128810 & RGD1565355 & -1.79 & $7.2 \mathrm{E}-04$ & 5.11 & 9.3E-05 \\
\hline A64P113795 & LOC100365047 & -1.58 & $1.2 \mathrm{E}-02$ & 2.06 & $3.9 \mathrm{E}-03$ \\
\hline A64P057188 & Shroom $2^{\mathrm{a}}$ & -1.52 & $5.5 \mathrm{E}-03$ & 1.73 & $1.6 \mathrm{E}-02$ \\
\hline A64P054808 & $\operatorname{CD} 36^{\mathrm{a}}$ & -1.47 & $1.1 \mathrm{E}-03$ & 6.98 & $1.5 E-04$ \\
\hline A44P305482 & Ppargcla & -1.43 & $3.9 \mathrm{E}-03$ & 1.48 & $1.6 \mathrm{E}-02$ \\
\hline A44P335776 & Chodl & -1.42 & $6.3 \mathrm{E}-03$ & 1.89 & $5.9 \mathrm{E}-03$ \\
\hline A44P158758 & Calcr & -1.40 & 1.3E-02 & 1.78 & $1.9 \mathrm{E}-02$ \\
\hline A64P15946 & $\operatorname{Pmp2}^{\mathrm{a}}$ & -1.16 & $1.4 \mathrm{E}-03$ & 5.24 & $1.5 \mathrm{E}-05$ \\
\hline A64P025432 & LOC498829 & -1.04 & $6.0 \mathrm{E}-03$ & 1.06 & 1.1. E-02 \\
\hline A44P194803 & Baalc & -1.03 & $3.1 \mathrm{E}-03$ & 1.93 & 7.0E-04 \\
\hline A64P137130 & Ptpre & -0.94 & $1.4 \mathrm{E}-02$ & 4.01 & $3.5 \mathrm{E}-04$ \\
\hline A44P254984 & Pnlip & -0.89 & 4.8E-03 & 0.92 & $5.2 \mathrm{E}-03$ \\
\hline A42P839964 & Plin2 & -0.79 & 8.7E-03 & 1.33 & $2.8 \mathrm{E}-03$ \\
\hline A42P826938 & LRRTM1 & -0.63 & $3.9 \mathrm{E}-03$ & 1.11 & $6.4 \mathrm{E}-04$ \\
\hline A42P646991 & Mag & -0.59 & 1.7E-02 & 1.34 & $7.9 \mathrm{E}-03$ \\
\hline
\end{tabular}

All the genes increased by EPO and inhibited by LIF at $20 \mathrm{~h}$ are listed. In bold the genes also increased by differentiation. The full list of the genes increased by EPO and differentiation at $20 \mathrm{~h}$ was previously reported (Gyetvai et al., 2017). a Genes represented by 2 probes consistently changed by EPO in the same direction, of which only the most significantly changed one is shown

pro-myelinating effects of other cytokines had not previously been reported.

LIF activates STAT3, which has a key role in myelination (Steelman et al., 2016). However, LIF signaling is tightly regulated. LIF-induced SOCS3, downstream of STAT3, inhibits STAT3 phosphorylation and excessive induction of inflammatory genes (Yasukawa et al., 2003), and is one of the main mechanisms through which LIF inhibits IL-6-induced differentiation of T helper (Th)17 cells (Cao et al., 2011). In the present study, LIF-induced SOCS3 expression was associated with a reduction of EPO-induced MOG at high concentration of LIF. In addition, also OSM and CNTF, cytokines of the IL- 6 family, used at equimolar LIF concentrations at which they induced similar levels of SOCS3 as compared to LIF (reported above in the Results section), inhibited EPO-induced MOG expression. These observations, together with previous results documenting increased myelination in SOCS3 knock-out mice (Emery et al., 2006), suggest that SOCS3 might play a role in LIF inhibition of $M O G$ expression. SOCS3 induction might explain the lower levels of MOG observed at high doses of LIF compared to low dose, and inhibition of EPO-induced MOG. Of note, SOCS3 can inhibit EPO-induced STAT5 activation (Sasaki et al., 2000; Bachmann et al., 2011).

We investigated whether LIF might directly inhibit the expression of positive regulators of myelination induced by EPO. By gene expression profiling, we found that LIF downregulated genes involved in lipid transport and metabolism previously found to be increased by EPO, including CD36, Ppargc1a, Pnlip and Plin2 (Gyetvai et al., 2017). Preferential downregulation of these genes by LIF strengthens the hypothesis that they might have a role in mediating EPO myelinating effects.

LIF inhibitory effects reported here cannot exclusively be correlated with an action on differentiated cells; LIF might also act on undifferentiated cells.

In this regard, LIF inhibited PTPRE, a tyrosine phosphatase induced by EPO that, among other effects, inhibits MAPK/ERK phosphorylation. We had previously shown that inhibitors of ERK in this system potentiate

Table 2 Enriched KEGG pathways and GO:BP categories among the genes increased by EPO and inhibited by LIF at $20 \mathrm{~h}$

\begin{tabular}{lllll}
\hline Category & Term & Fold enrichment & Gene symbols & $P$ value \\
\hline KEGG & Fat digestion and absorption & 87.7 & Pnlip, CD36, RGD1565355 & $3.4 \mathrm{E}-04$ \\
KEGG & Adipocytokine signaling pathway & 44.5 & CD36, Ppargcla, RGD1565355 & PnlipP, CD36 \\
GO:BP & Intestinal cholesterol absorption & 730.6 & CD36, Ppargcla, RGD1565355 \\
KEGG & Insulin resistance & 30.3 & CD36, Plin2, Htr2c, PPARGC1A \\
GO:BP & Response to drug & 11.1 & CD36, PPARGC1A, RGD1565355 \\
KEGG & AMPK signaling pathway & 26.3 & Calcr, CD36, RGD1565355 \\
GO:BP & Cell surface receptor signaling pathway & 22.8 & CD36, Plin2 & $3.9 \mathrm{E}-03$ \\
GO:BP & Long-chain fatty acid transport & 243.5 & CD36, Ppargcla & $3.8 \mathrm{E}-03$ \\
GO:BP & Fatty acid oxidation & 182.7 & CD36, Plin2 & 6.1E-03 \\
GO:BP & Lipid storage & 108.2 & Pnlip, CD36 & 7.5E-03 \\
GO:BP & Response to lipid & 97.4 & Calcr, CD36 & $1.0 \mathrm{E}-02$ \\
GO:BP & Receptor internalization & 69.6 & CD36, RGD1565355 \\
KEGG & Malaria & 37.7 & $1.7 \mathrm{E}-02$ \\
\hline
\end{tabular}

DAVID Functional Annotation Chart analysis showing the overrepresented GO:BP categories and KEGG pathways among the genes increased by EPO and decreased by LIF at $20 \mathrm{~h}$. The fold enrichment and the significance of enrichment ( $P$ value) are reported 

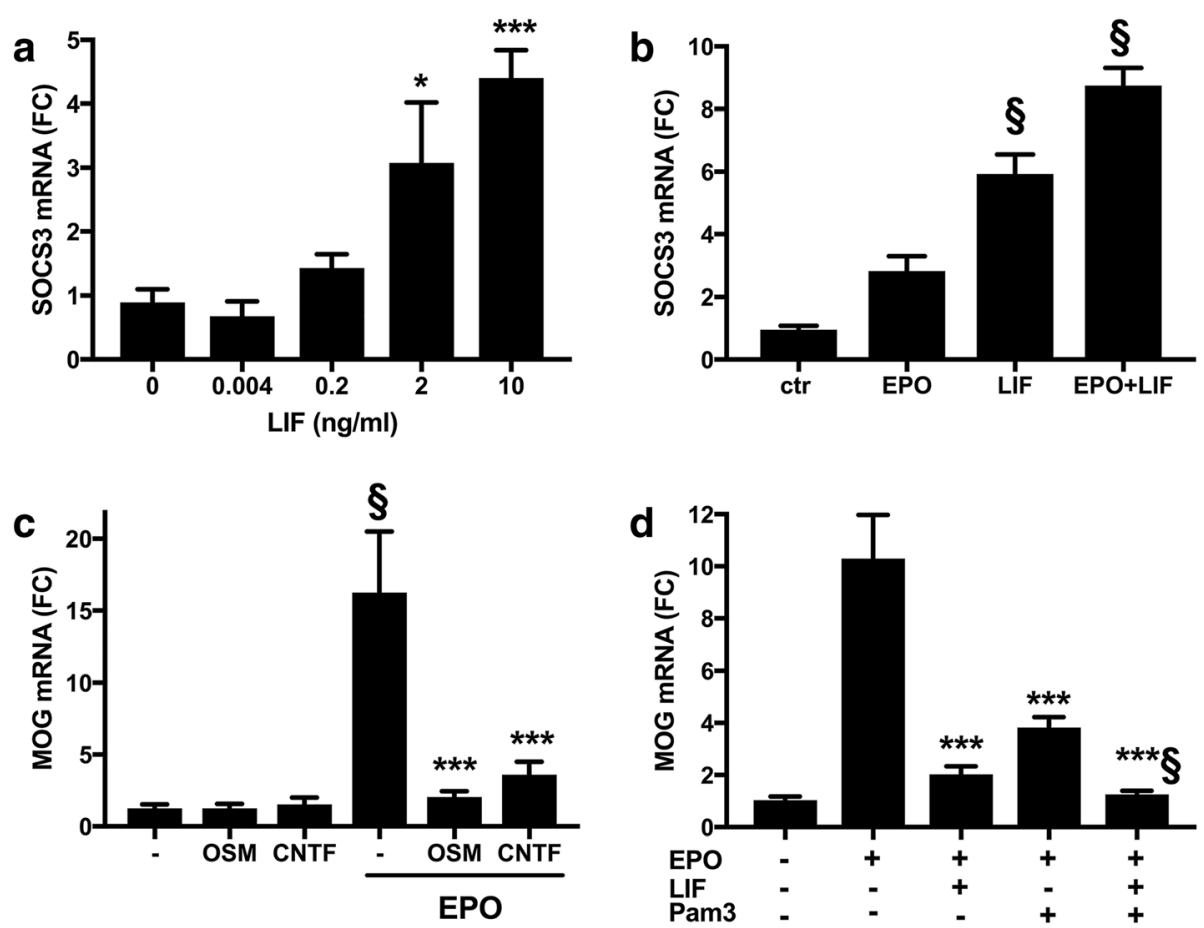

Fig. 4 Role of SOCS3 and TLR2 in mediating LIF inhibition. a-b LIF induction of SOCS3 is associated with a reduction in MOG expression (shown in Fig. 1). Cells cultured for 1 day in GM were switched to DM; after $3 \mathrm{~h}$ they were treated with the indicated concentrations of LIF (a), or with or without EPO $(10 \mathrm{ng} / \mathrm{ml})$ and LIF $(10 \mathrm{ng} / \mathrm{ml}$; b). After $1 \mathrm{~h}$, SOCS3 mRNA was measured by RT-qPCR. Results, expressed as fold change (FC) vs one of the control (ctr) samples (no LIF in $\mathbf{a}$ ) are the mean \pm SD of quadruplicate samples assayed in duplicate and are representative of two independent experiments; ${ }^{*} P<0.05,{ }^{* * *} P<0.001$ vs control (no LIF); $\S P<0.001$ vs EPO by two-tailed Student's $t$-test. c OSM and CNTF inhibit EPO-induced MOG expression. Cells cultured as above were treated with or without EPO $(10 \mathrm{ng} / \mathrm{ml})$ and OSM or CNTF (both at $6.5 \mathrm{ng} / \mathrm{ml}$, equimolar concentrations to LIF $10 \mathrm{ng} / \mathrm{ml}$ ). MOG gene expression was measured by RT-qPCR at day 3 . Results, expressed as above, are the mean \pm SD of eight samples from two independent experiments assayed in duplicate; ${ }^{* * *} P<0.001 \mathrm{vs} \mathrm{EPO} \mathrm{alone;} \S P<0.001$ vs untreated by two-tailed Student's t-test. $\mathbf{d}$ TLR2 engagement inhibits EPO-induced MOG expression. Cells were differentiated in the absence or in the presence of EPO $(10 \mathrm{ng} / \mathrm{ml})$, with or without LIF $(10 \mathrm{ng} / \mathrm{ml})$ or Pam3 $(1 \mu \mathrm{g} / \mathrm{ml})$, a TLR2/1 ligand. MOG expression was measured at day 3 by RT-qPCR. Results, expressed as above, are the mean \pm SD of quadruplicate samples assayed in duplicate and are representative of two independent experiments; ${ }^{* * *} P<0.001$ vs EPO alone; $\S P<0.01$ vs EPO + LIF by two-tailed Student's $t$-test

myelination, in support of the hypothesis that activation of ERK might sustain proliferation of OPCs and inhibit the start of differentiation (Gyetvai et al., 2017). Both EPO and LIF can induce ERK activation (Gyetvai et al., 2017; Nicola \& Babon, 2015). However, EPO induces the feedback inhibitor PTPRE. Inhibition of PTPRE by LIF might prolong ERK activation in OPCs, inhibiting differentiation.

In addition, other than being pro-myelinating cytokines, LIF and other members of the IL- 6 family, such as CNTF, are essential in development for inducing astrocyte differentiation. LIF can also increase astrocyte differentiation in vitro, although the presence of extracellular matrix factors may be required (Nicola \& Babon, 2015). CG4 cells are bipotential OL type- 2 astrocyte $(\mathrm{O}-2 \mathrm{~A})$ progenitors that can be induced to differentiate into type- 2 astrocytes or into mature OLs (Louis et al., 1992; Solly et al., 1996). In primary OLs and CG4 cells LIF can induce the astrocyte marker GFAP (Kahn \& De Vellis, 1994; Gresle et al., 2015), an observation that we have confirmed (Additional file 4). It is therefore possible that LIF, if present at the very early stages of the OL differentiation process, could interfere by inducing astrocyte differentiation. Although this is a very controversial issue, the presence of $\mathrm{O}-2 \mathrm{~A}$ progenitors in vivo, and even in pathological conditions, has been suggested (Franklin \& Blakemore, 1995; Virard et al., 2006).

Among the possible negative regulators induced by LIF, we noticed components of the TLR pathways, including TLR2 and Myd88, an adaptor protein used by almost all TLRs. Other than microbial products, the TLRs recognize endogenous danger-associated molecular patterns (DAMPs) released from injured tissues which regulate inflammatory responses (Lee et al., 2013). All cells of the CNS express the TLRs, including OLs which preferentially express TLR2 and TLR3 (Bsibsi et al., 2002; Sloane et al., 2010). TLR2 is upregulated in experimental models of MS and in MS demyelinating lesions, where it is also expressed by OLs (Sloane et al., 2010; Zekki et al., 2002; Esser et al., 2018); TLR2 activation inhibits OL maturation, an effect not shared by all TLRs (Sloane et al., 2010). We show here that TLR2 is 
functional in OLs, and its activation inhibits myelin gene expression.

Whether TLR2 has a role in mediating LIF inhibitory effects will of course depend on the presence of TLR2 ligands. TLR2, by forming homodimers and heterodimers with TLR1 or TLR6, can bind a broad range of ligands, including Gram-positive bacterial cell wall components, endogenous DAMPs such as heat shock proteins (HSPs) and high mobility group protein B1 (HMGB1), and fragments of extracellular matrix (ECM) molecules, such as hyaluronan (Piccinini \& Midwood, 2010; Miranda-Hernandez \& Baxter, 2013). Of note, TLR2 ligands, including hyaluronan, HMGB1 and peptidoglycan, a component of Gram-positive bacteria, have been detected in EAE and in MS lesions (Back et al., 2005; Visser et al., 2006; Andersson et al., 2008), suggesting that LIF-induction of TLR2 in OLs might actually lead to inhibition of remyelination.

Although LIF has an important role in promoting myelination (Slaets et al., 2010; Stankoff et al., 2002; Metcalfe, 2018), its pleiotropic nature, and its ability to induce proliferation inhibiting differentiation or vice versa, may result in negative myelinating effects at certain stages of the myelination process, likely when undifferentiated OL progenitors should stop proliferating and start differentiating. In pathological conditions, including MS, remyelination, especially at later disease stages, is insufficient to re-establish motor and cognitive performance. MS lesions may contain large numbers of poorly differentiated OPCs and immature OLs, suggesting that in many cases the main cause of remyelination failure is not a lack of OPCs, but rather an inability of these cells to differentiate into mature myelin producing cells (Franklin \& Gallo, 2014; Kremer et al., 2015; Chamberlain et al., 2016). The presence of LIF in MS lesions (Vanderlocht et al., 2006) might contribute to inhibit OPC differentiation and remyelination.

Moreover, our findings show that, when considering the action of cytokines on myelination, one should consider that they act on a tightly regulated network, where each cytokine can affect the action of another. Identifying these regulatory networks may be important as different cytokines may be up- or down-regulated in disease conditions and this may have pharmacological relevance when cytokines are administered as neuroprotective or neuroreparative agents. Although the effectiveness of EPO in MS is unclear and recent clinical trials have not shown an efficacy (Schreiber et al., 2017), research is still active on EPO mimetics or derivatives with different biological properties (Culver et al., 2017; Bonnas et al., 2017); clinical trials with EPO in optic neuritis are ongoing after positive indications from phase 2 trials (Suhs et al., 2012; Diem et al., 2016) and its use to improve traumatic brain injury is still open (Counter et al., 1994). Likewise, there is interest in the potential use of LIF in the therapy of MS (Slaets et al., 2010; Metcalfe, 2018). The tight regulation of LIF signaling pathways that might negatively affect remyelination, shown here, needs to be taken into account in designing combination therapies and dose-finding studies. Additionally, increased blood and cerebrospinal fluid levels of LIF (Mashayekhi \& Salehi, 2011), IL-11 (Zhang et al., 2015), CNTF (Massaro et al., 1997) and IL-6 (Wullschleger et al., 2013) have been found in MS patients, thus raising the possibility of them affecting the response to EPO.

Of course we should bear in mind the limitations of our study. The use of a cell line, although largely used for basic studies on myelination, limits the external validity of our findings, and only in vivo experiments in models of demyelination could indicate the in vivo relevance of the pathways that we have identified.

\section{Conclusion}

This study reports that the IL- 6 family cytokine LIF can inhibit EPO-induced myelin gene expression in OLs. LIF's promyelinating effects have long been known, but controversial results have also been reported. The pleiotropic activities of LIF, which can inhibit or stimulate proliferation or differentiation and exhibit inflammatory or anti-inflammatory action, together with the tight inhibitory feedback mechanisms that regulate its signaling pathways, and its ability to induce negative regulators, such as TLR2, can translate into inhibition of myelination, depending on the stage of OL differentiation and on the cytokine environment. Further studies on the mechanisms by which endogenous cytokines positively and negatively affect myelination may lead to the identification of therapeutic targets and new drugs essential to improve remyelination in demyelinating diseases.

\section{Additional files}

Additional file 1: Genes increased by EPO in differentiating cells at $1 \mathrm{~h}$. Genes changed more than 1.5-fold (absolute $\log _{2} \mathrm{FC}>0.58$ ), $\mathrm{BH}$ adj. $P$ value $<0.05$ in EPO-treated vs untreated differentiating cells are listed; $\mathrm{ns}=$ not significant. There were no genes decreased by EPO at this time point. The relative change in differentiating (dif) vs undifferentiated (undif) cells and in EPO + LIF vs EPO-treated cells are also reported. *Represented by 2 probes consistently increased by EPO of which only the most significantly changed one is shown (XIsx file). (XLSX 10 kb)

Additional file 2: Genes increased by LIF and by differentiation at $1 \mathrm{~h}$. These genes have been identified by comparing EPO + LIF vs EPO and differentiating (dif) vs undifferentiated (undif) cells, setting a threshold of $\log _{2} \mathrm{FC} \geq 0.58$ and $\mathrm{BH}$ adj. $P$ value $<0.05$. ${ }^{*}$ Represented by 2 probes consistently increased by LIF of which only the most significantly changed one is shown (xIsx file). (XLSX $10 \mathrm{~kb}$ )

Additional file 3: Genes increased by LIF and unchanged or decreased by differentiation or EPO at $1 \mathrm{~h}$. The genes increased more than 1.5-fold $\left(\log _{2} \mathrm{FC} \geq 0.58\right), \mathrm{BH}$ adj. $P$ value $<0.05$ in EPO + LIF vs EPO-treated differentiating cells are listed; $n s=$ not significant. For genes represented by 2 probes $\left(^{*}\right)$ consistently increased by LIF, only the one increased more significantly is shown (xlsx file). (XLSX $20 \mathrm{~kb}$ )

Additional file 4: Genes increased by LIF and unchanged or decreased by differentiation or EPO at $20 \mathrm{~h}$. The genes increased more than 1.5-fold 
$\left(\log _{2} \mathrm{FC} \geq 0.58\right), \mathrm{BH}$ adj. $P$ value $<0.05$ in EPO + LIF vs EPO-treated differentiating cells are listed; $n s=$ not significant. For genes represented by 2 probes $\left(^{*}\right)$ consistently increased by LIF, only the one increased more significantly is shown (xlsx file). (XLSX $63 \mathrm{~kb}$ )

\section{Abbreviations}

BH: Benjamini-Hochberg; CD36: Cluster of differentiation 36; CG4: Central glia-4; CNS: Central nervous system; CNTF: Ciliary neurotrophic factor; DAMP: Damage-associated molecular patterns; DAVID: Database for Annotation, Visualization and Integrated Discovery; DM: Differentiation medium; EPO: Erythropoietin; EPOR: Erythropoietin receptor; ERK: Extracellular signal-regulated kinases; GM: Growth medium; GO:BP: Gene ontology biological process; gp130: Glycoprotein 130; HPRT1: Hypoxanthine phosphoribosyltransferase 1; HSP: Heat shock protein; JAK: Janus kinase; LIF: Leukemia inhibitory factor; LIFR: Leukemia inhibitory factor receptor; MAPK: Mitogen-activated protein kinase; MOG: Myelin oligodendrocyte glycoprotein; MS: Multiple sclerosis; Myd88: Myeloid differentiation primary response 88; O-2A: Oligodendrocyte-type-2 astrocyte; OL: Oligodendrocyte; OPC: Oligodendrocyte progenitor cell; OSM: Oncostatin M; PI3K: Phosphatidylinositol-3-kinase; Plin2: Perilipin 2; Pnlip: Pancreatic lipase; Ppargc1a: Peroxisome proliferator-activated receptor gamma coactivator 1 alpha; Ptpre: Protein tyrosine phosphatase receptor type E; QPCR: Quantitative polymerase chain reaction; RT: Reverse transcription; SOCS3: Suppressor of cytokine signaling 3; STAT3: Signal transducer and activator of transcription 3; STRING: Search Tool for the Retrieval of Interacting Genes; TLR: Toll like receptor

\section{Acknowledgments}

The authors thank Alexander Annenkov for providing the CG4-EPOR cells used in this study.

\section{Funding}

Supported by the RM Philips Trust (PG), the Brighton Centre for Regenerative Medicine and Devices (CRMD), University of Brighton (GG) and the Brighton and Sussex Medical School as part of the Independent Research Project of CR.

\section{Availability of data and materials}

The microarray datasets generated during the current study are available in the GEO database of NCBI (http://www.ncbi.nlm.nih.gov/geo) at GEO Series accession number GSE84687.

\section{Authors' contributions}

$\mathrm{GG}, \mathrm{CR}, \mathrm{LH}, \mathrm{MM}$ performed experiments, analyzed and interpreted results; GG, MM, PG designed experiments; GG, MM and PG wrote the manuscript; all authors critically revised and approved the final manuscript. All authors read and approved the final manuscript.

\section{Ethics approval}

Not applicable.

\section{Consent for publication}

Not applicable.

\section{Competing interests}

The authors declare they have no competing interests as defined by Molecular Medicine, or other interests that might be perceived to influence the results and discussion reported in this paper.

\section{Publisher's Note}

Springer Nature remains neutral with regard to jurisdictional claims in published maps and institutional affiliations.

\section{Received: 30 April 2018 Accepted: 14 September 2018} Published online: 27 September 2018

\section{References}

Andersson A, Covacu R, Sunnemark D, Danilov Al, Dal Bianco A, Khademi M, Wallstrom E, Lobell A, Brundin L, Lassmann H, et al. Pivotal advance: HMGB1 expression in active lesions of human and experimental multiple sclerosis. J Leukoc Biol. 2008;84(5):1248-55.

Bachmann J, Raue A, Schilling M, Bohm ME, Kreutz C, Kaschek D, Busch H, Gretz $\mathrm{N}$, Lehmann WD, Timmer J, et al. Division of labor by dual feedback regulators controls JAK2/STAT5 signaling over broad ligand range. Mol Syst Biol. 2011;7:516.

Back SA, Tuohy TM, Chen H, Wallingford N, Craig A, Struve J, Luo NL, Banine F, Liu Y, Chang A, et al. Hyaluronan accumulates in demyelinated lesions and inhibits oligodendrocyte progenitor maturation. Nat Med. 2005;11(9):966-72.

Barres BA, Schmid R, Sendnter M, Raff MC. Multiple extracellular signals are required for long-term oligodendrocyte survival. Development. 1993;118(1): 283-95.

Barrett T, Wilhite SE, Ledoux P, Evangelista C, Kim IF, Tomashevsky M, Marshall KA, Phillippy KH, Sherman PM, Holko M, et al. NCBI GEO: archive for functional genomics data sets--update. Nucleic Acids Res. 2013;41(Database issue):D991-5.

Bonnas C, Wustefeld L, Winkler D, Kronstein-Wiedemann R, Dere E, Specht K, Boxberg M, Tonn T, Ehrenreich $\mathrm{H}$, Stadler $\mathrm{H}$, et al. EV-3, an endogenous human erythropoietin isoform with distinct functional relevance. Sci Rep. 2017;7(1):3684.

Bove RM, Green AJ. Remyelinating pharmacotherapies in multiple sclerosis. Neurotherapeutics. 2017;14(4):894-904

Bsibsi M, Ravid R, Gveric D, van Noort JM. Broad expression of toll-like receptors in the human central nervous system. J Neuropathol Exp Neurol. 2002;61(11): 1013-21.

Cadavid D, Balcer L, Galetta S, Aktas O, Ziemssen T, Vanopdenbosch L, Frederiksen J, Skeen M, Jaffe GJ, Butzkueven H, et al. Safety and efficacy of opicinumab in acute optic neuritis (RENEW): a randomised, placebocontrolled, phase 2 trial. Lancet Neurol. 2017;16(3):189-99.

Cao W, Yang Y, Wang Z, Liu A, Fang L, Wu F, Hong J, Shi Y, Leung S, Dong C, et al. Leukemia inhibitory factor inhibits $T$ helper 17 cell differentiation and confers treatment effects of neural progenitor cell therapy in autoimmune disease. Immunity. 2011;35(2):273-84.

Cervellini I, Annenkov A, Brenton T, Chernajovsky Y, Ghezzi P, Mengozzi M. Erythropoietin (EPO) increases myelin gene expression in CG4 oligodendrocyte cells through the classical EPO receptor. Mol Med. 2013;19: 223-9.

Chamberlain KA, Nanescu SE, Psachoulia K, Huang JK. Oligodendrocyte regeneration: its significance in myelin replacement and neuroprotection in multiple sclerosis. Neuropharmacology. 2016;110(Pt B):633-43. https://doi. org/10.1016/j.neuropharm.2015.10.010.

Counter CM, Botelho FM, Wang P, Harley CB, Bacchetti S. Stabilization of short telomeres and telomerase activity accompany immortalization of Epstein-Barr virus-transformed human B lymphocytes. J Virol. 1994;68(5):3410-4.

Culver DA, Dahan A, Bajorunas D, Jeziorska M, van Velzen M, Aarts L, Tavee J, Tannemaat MR, Dunne AN, Kirk Rl, et al. Cibinetide improves corneal nerve Fiber abundance in patients with sarcoidosis-associated small nerve Fiber loss and neuropathic pain. Invest Ophthalmol Vis Sci. 2017;58(6):BIO52-60.

Davis SM, Pennypacker KR. The role of the leukemia inhibitory factor receptor in neuroprotective signaling. Pharmacol Ther. 2018;183:50-7.

Diem R, Molnar F, Beisse F, Gross N, Druschler K, Heinrich SP, Joachimsen L, Rauer $\mathrm{S}$, Pielen A, Suhs KW, et al. Treatment of optic neuritis with erythropoietin (TONE): a randomised, double-blind, placebo-controlled trial-study protocol. BMJ Open. 2016;6(3):e010956.

Digicaylioglu M, Garden G, Timberlake S, Fletcher L, Lipton SA. Acute neuroprotective synergy of erythropoietin and insulin-like growth factor I. Proc Natl Acad Sci USA. 2004;101(26):9855-60.

Ehrenreich H, Fischer B, Norra C, Schellenberger F, Stender N, Stiefel M, Siren AL, Paulus W, Nave KA, Gold R, et al. Exploring recombinant human erythropoietin in chronic progressive multiple sclerosis. Brain. 2007;130(Pt 10): 2577-88.

Emery B, Cate HS, Marriott M, Merson T, Binder MD, Snell C, Soo PY, Murray S, Croker B, Zhang JG, et al. Suppressor of cytokine signaling 3 limits protection of leukemia inhibitory factor receptor signaling against central demyelination. Proc Natl Acad Sci U S A. 2006;103(20):7859-64.

Esser S, Gopfrich L, Bihler K, Kress E, Nyamoya S, Tauber SC, Clarner T, Stope MB, Pufe T, Kipp M, et al. Toll-like receptor 2-mediated glial cell activation in a mouse model of Cuprizone-induced demyelination. Mol Neurobiol. 2018; 55(8):6237-49. https://doi.org/10.1007/s12035-017-0838-2.

Franklin RJ, Blakemore WF. Glial-cell transplantation and plasticity in the O-2A lineage--implications for CNS repair. Trends Neurosci. 1995;18(3):151-6. 
Franklin RJ, Gallo V. The translational biology of remyelination: past, present, and future. Glia. 2014;62(11):1905-15.

Green AJ, Gelfand JM, Cree BA, Bevan C, Boscardin WJ, Mei F, Inman J, Arnow S, Devereux $M$, Abounasr $A$, et al. Clemastine fumarate as a remyelinating therapy for multiple sclerosis (ReBUILD): a randomised, controlled, doubleblind, crossover trial. Lancet. 2017;390(10111):2481-9.

Gresle MM, Butzkueven H, Perreau VM, Jonas A, Xiao J, Thiem S, Holmes FE, Doherty W, Soo PY, Binder MD, et al. Galanin is an autocrine myelin and oligodendrocyte trophic signal induced by leukemia inhibitory factor. Glia. 2015;63(6):1005-20.

Gyetvai G, Hughes T, Wedmore F, Roe C, Heikal L, Ghezzi P, Mengozzi M. Erythropoietin increases myelination in oligodendrocytes: gene expression profiling reveals early induction of genes involved in lipid transport and metabolism. Front Immunol. 2017;8:1394.

Hassouna I, Ott C, Wustefeld L, Offen N, Neher RA, Mitkovski M, Winkler D, Sperling $S$, Fries $L$, Goebbels $S$, et al. Revisiting adult neurogenesis and the role of erythropoietin for neuronal and oligodendroglial differentiation in the hippocampus. Mol Psychiatry. 2016;21(12):1752-67.

Huang da W, Sherman BT, Lempicki RA. Systematic and integrative analysis of large gene lists using DAVID bioinformatics resources. Nat Protoc. 2009;4(1): 44-57.

Ishibashi T, Dakin KA, Stevens B, Lee PR, Kozlov SV, Stewart CL, Fields RD. Astrocytes promote myelination in response to electrical impulses. Neuron. 2006;49(6):823-32.

Kahn MA, De Vellis J. Regulation of an oligodendrocyte progenitor cell line by the interleukin-6 family of cytokines. Glia. 1994;12(2):87-98.

Kang YJ, Digicaylioglu M, Russo R, Kaul M, Achim CL, Fletcher L, Masliah E, Lipton SA. Erythropoietin plus insulin-like growth factor-I protects against neuronal damage in a murine model of human immunodeficiency virus-associated neurocognitive disorders. Ann Neurol. 2010;68(3):342-52.

Kremer D, Kury P, Dutta R. Promoting remyelination in multiple sclerosis: current drugs and future prospects. Mult Scler. 2015;21(5):541-9.

Lee H, Lee S, Cho IH, Lee SJ. Toll-like receptors: sensor molecules for detecting damage to the nervous system. Curr Protein Pept Sci. 2013;14(1):33-42.

Li XB, Zheng W, Ning YP, Cai DB, Yang XH, Ungvari GS, Ng CH, Wang CY, Xiang YT. Erythropoietin for cognitive deficits associated with schizophrenia, bipolar disorder, and major depression: a systematic review. Pharmacopsychiatry. 2018:51(3):100-4.

Linker RA, Kruse N, Israel S, Wei T, Seubert S, Hombach A, Holtmann B, Luhder F, Ransohoff RM, Sendtner M, et al. Leukemia inhibitory factor deficiency modulates the immune response and limits autoimmune demyelination: a new role for neurotrophic cytokines in neuroinflammation. J Immunol. 2008; 180(4):2204-13.

Louis JC, Magal E, Muir D, Manthorpe M, Varon S. CG-4, a new bipotential glial cell line from rat brain, is capable of differentiating in vitro into either mature oligodendrocytes or type-2 astrocytes. J Neurosci Res. 1992;31(1):193-204.

Marriott MP, Emery B, Cate HS, Binder MD, Kemper D, Wu Q, Kolbe S, Gordon IR, Wang $H$, Egan $G$, et al. Leukemia inhibitory factor signaling modulates both central nervous system demyelination and myelin repair. Glia. 2008;56(6): 686-98.

Martino G, Pluchino S. The therapeutic potential of neural stem cells. Nat Rev Neurosci. 2006;7(5):395-406.

Mashayekhi F, Salehi Z. Expression of leukemia inhibitory factor in the cerebrospinal fluid of patients with multiple sclerosis. J Clin Neurosci. 2011; 18(7):951-4.

Massaro AR, Soranzo C, Carnevale A. Cerebrospinal-fluid ciliary neurotrophic factor in neurological patients. Eur Neurol. 1997;37(4):243-6.

Mengozzi M, Cervellini I, Villa P, Erbayraktar Z, Gokmen N, Yilmaz O, Erbayraktar S, Manohasandra M, Van Hummelen P, Vandenabeele P, et al. Erythropoietininduced changes in brain gene expression reveal induction of synaptic plasticity genes in experimental stroke. Proc Natl Acad Sci USA. 2012;109(24): 9617-22.

Mengozzi M, Ermilov P, Annenkov A, Ghezzi P, Pearl F. Definition of a family of tissue-protective cytokines using functional cluster analysis: a proof-ofconcept study. Front Immunol. 2014;5:115.

Metcalfe SM. LIF and multiple sclerosis: one protein with two healing properties. Mult Scler Relat Disord. 2018;20:223-7.

Miranda-Hernandez S, Baxter AG. Role of toll-like receptors in multiple sclerosis. Am J Clin Exp Immunol. 2013;2(1):75-93.

Nicola NA, Babon JJ. Leukemia inhibitory factor (LIF). Cytokine Growth Factor Rev. 2015;26(5):533-44.
Ott C, Martens H, Hassouna I, Oliveira B, Erck C, Zafeiriou MP, Peteri UK, Hesse D, Gerhart S, Altas B, et al. Widespread expression of erythropoietin receptor in brain and its induction by injury. Mol Med. 2015;21(1):803-15. https://doi.org/ 10.2119/molmed.2015.00192.

Park SK, Solomon D, Vartanian T. Growth factor control of CNS myelination. Dev Neurosci. 2001;23(4-5):327-37.

Philips T, Rothstein JD. Oligodendroglia: metabolic supporters of neurons. J Clin Invest. 2017;127(9):3271-80.

Piccinini AM, Midwood KS. DAMPening inflammation by modulating TLR signalling. Mediat Inflamm. 2010;2010:672395. https://doi.org/10.1155/2010/672395.

Robinson S, Winer JL, Chan LAS, Oppong AY, Yellowhair TR, Maxwell JR, Andrews N, Yang Y, Sillerud LO, Meehan WP 3rd, et al. Extended erythropoietin treatment prevents chronic executive functional and microstructural deficits following early severe traumatic brain injury in rats. Front Neurol. 2018;9:451.

Ruckh JM, Zhao JW, Shadrach JL, van Wijngaarden P, Rao TN, Wagers AJ, Franklin RJ. Rejuvenation of regeneration in the aging central nervous system. Cell Stem Cell. 2012;10(1):96-103.

Sargin D, Friedrichs H, El-Kordi A, Ehrenreich H. Erythropoietin as neuroprotective and neuroregenerative treatment strategy: comprehensive overview of 12 years of preclinical and clinical research. Best Pract Res Clin Anaesthesiol. 2010;24(4):573-94.

Sasaki A, Yasukawa H, Shouda T, Kitamura T, Dikic I, Yoshimura A. CIS3/SOCS-3 suppresses erythropoietin (EPO) signaling by binding the EPO receptor and JAK2. J Biol Chem. 2000;275(38):29338-47.

Schreiber K, Magyari M, Sellebjerg F, Iversen P, Garde E, Madsen CG, Bornsen L, Romme Christensen J, Ratzer R, Siebner HR, et al. High-dose erythropoietin in patients with progressive multiple sclerosis: a randomized, placebocontrolled, phase 2 trial. Mult Scler. 2017;23(5):675-85.

Siren AL, Knerlich F, Poser W, Gleiter CH, Bruck W, Ehrenreich H. Erythropoietin and erythropoietin receptor in human ischemic/hypoxic brain. Acta Neuropathol. 2001;101(3):271-6.

Slaets H, Hendriks JJ, Stinissen P, Kilpatrick TJ, Hellings N. Therapeutic potential of LIF in multiple sclerosis. Trends Mol Med. 2010;16(11):493-500.

Sloane JA, Batt C, Ma Y, Harris ZM, Trapp B, Vartanian T. Hyaluronan blocks oligodendrocyte progenitor maturation and remyelination through TLR2. Proc Natl Acad Sci U S A. 2010;107(25):11555-60.

Solly SK, Thomas JL, Monge M, Demerens C, Lubetzki C, Gardinier MV, Matthieu $J M$, Zalc B. Myelin/oligodendrocyte glycoprotein (MOG) expression is associated with myelin deposition. Glia. 1996;18(1):39-48.

Stankoff B, Aigrot MS, Noel F, Wattilliaux A, Zalc B, Lubetzki C. Ciliary neurotrophic factor (CNTF) enhances myelin formation: a novel role for CNTF and CNTF-related molecules. J Neurosci. 2002;22(21):9221-7.

Steelman AJ, Zhou Y, Koito H, Kim S, Payne HR, Lu QR, Li J. Activation of oligodendroglial Stat3 is required for efficient remyelination. Neurobiol Dis. 2016;91:336-46.

Sugawa M, Sakurai Y, Ishikawa-leda Y, Suzuki H, Asou H. Effects of erythropoietin on glial cell development; oligodendrocyte maturation and astrocyte proliferation. Neurosci Res. 2002;44(4):391-403.

Suhs KW, Hein K, Sattler MB, Gorlitz A, Ciupka C, Scholz K, Kasmann-Kellner B, Papanagiotou P, Schaffler N, Restemeyer C, et al. A randomized, double-blind, phase 2 study of erythropoietin in optic neuritis. Ann Neurol. 2012;72(2):199-210.

Takahashi A, Takahashi Y, Matsumoto K, Miyata K. Synergistic effects of insulin-like growth factor II (IGF-II) with leukemia inhibiting factor (LIF) on establishment of rat pluripotential cell lines. J Vet Med Sci. 1995;57(3):553-6.

Tauheed AM, Ayo JO, Kawu MU. Regulation of oligodendrocyte differentiation: insights and approaches for the management of neurodegenerative disease. Pathophysiology. 2016;23(3):203-10.

Ulich TR, Fann MJ, Patterson PH, Williams JH, Samal B, Del Castillo J, Yin S, Guo K, Remick DG. Intratracheal injection of LPS and cytokines. V. LPS induces expression of LIF and LIF inhibits acute inflammation. Am J Phys. 1994;267(4 Pt 1):L442-6.

Vanderlocht J, Hellings N, Hendriks JJ, Vandenabeele F, Moreels M, Buntinx M, Hoekstra D, Antel JP, Stinissen P. Leukemia inhibitory factor is produced by myelin-reactive T cells from multiple sclerosis patients and protects against tumor necrosis factor-alpha-induced oligodendrocyte apoptosis. J Neurosci Res. 2006;83(5):763-74.

Vela L, Caballero I, Fang L, Liu Q, Ramon F, Diez E, de Los Frailes M. Discovery of enhancers of the secretion of leukemia inhibitory factor for the treatment of multiple sclerosis. J Biomol Screen. 2016;21(5):437-45.

Virard I, Coquillat D, Bancila M, Kaing S, Durbec P. Oligodendrocyte precursor cells generate pituicytes in vivo during neurohypophysis development. Glia. 2006;53(3):294-303. 
Visser L, Melief MJ, van Riel D, van Meurs M, Sick EA, Inamura S, Bajramovic JJ, Amor S, Hintzen RQ, Boven LA, et al. Phagocytes containing a diseasepromoting toll-like receptor/nod ligand are present in the brain during demyelinating disease in primates. Am J Pathol. 2006;169(5):1671-85.

Willson TA, Metcalf D, Gough NM. Cross-species comparison of the sequence of the leukaemia inhibitory factor gene and its protein. Eur J Biochem. 1992; 204(1):21-30

Wullschleger A, Kapina V, Molnarfi N, Courvoisier DS, Seebach JD, Santiago-Raber ML, Hochstrasser DF, Lalive PH. Cerebrospinal fluid interleukin-6 in central nervous system inflammatory diseases. PLoS One. 2013;8(8):e72399.

Yasukawa H, Ohishi M, Mori H, Murakami M, Chinen T, Aki D, Hanada T, Takeda K Akira S, Hoshijima M, et al. IL-6 induces an anti-inflammatory response in the absence of SOCS3 in macrophages. Nat Immunol. 2003;4(6):551-6.

Zekki H, Feinstein DL, Rivest S. The clinical course of experimental autoimmune encephalomyelitis is associated with a profound and sustained transcriptional activation of the genes encoding toll-like receptor 2 and CD14 in the mouse CNS. Brain Pathol. 2002;12(3):308-19.

Zhang X, Tao Y, Chopra M, Dujmovic-Basuroski I, Jin J, Tang Y, Drulovic J, Markovic-Plese S. IL-11 induces Th17 cell responses in patients with early relapsing-remitting multiple sclerosis. J Immunol. 2015;194(11):5139-49.

Ready to submit your research? Choose BMC and benefit from:

- fast, convenient online submission

- thorough peer review by experienced researchers in your field

- rapid publication on acceptance

- support for research data, including large and complex data types

- gold Open Access which fosters wider collaboration and increased citations

- maximum visibility for your research: over $100 \mathrm{M}$ website views per year

At BMC, research is always in progress.

Learn more biomedcentral.com/submissions 